\title{
Did the United States Miss Its Chance to Benefit from Ongoing Asia-Pacific Trade Agreements?
}

\author{
Wendy Cutler
}

\begin{abstract}
This essay contends that it is in the US interest to become fully engaged in the Asian economic landscape. Twenty years ago, Asia accounted for less than a third of global output. Twenty years from now, Asia will account for more than half the world's total economy. Today, Asia is home to a burgeoning middle class and and a growing and dynamic market to many of the countries and companies that will shape the global economy for years to come. As most countries in the region have moved to put in place extensive trade agreements, including the Regional Comprehensive Economic Partnership (RCEP), the Comprehensive and Progressive Agreement for Trans-Pacific Partnership ( $C P T P P)$, and numerous bilateral and sectoral agreements, the US has substantially withdrawn from participating. Since the US exit from the Trans-Pacific Partnership (TPP) in 2017, there has been a steady march of new trade agreements across the Asia-Pacific region that do not include the United States. If this trend continues, there is a serious danger that the US will miss its window of opportunity to shape trade rules and norms within the largest and most rapidly growing region in the world.
\end{abstract}

Keywords US strategic foreign trade policies - Asia is home to a burgeoning middle class $\cdot$ RCEP $\cdot$ CPTPP $\cdot$ US exit from the TPP $\cdot$ New free trade agreements (FTA's)across the Asia-Pacific region

W. Cutler $(\bowtie)$

Asia Society Policy Institute (ASPI), Washington, D.C., USA

(C) The Author(s) 2021

H. Wang and A. Michie (eds.), Consensus or Conflict?, China and Globalization, https://doi.org/10.1007/978-981-16-5391-9_25 
Twenty years ago, Asia accounted for less than a third of global output. Twenty years from now, it will account for more than half the world's total economy. Asia is today home to a burgeoning middle class and a growing and dynamic market to many of the countries and companies that will shape the global economy for years to come. As most countries in the region have moved to put in place extensive trade agreements - including the RCEP, ${ }^{1}$ the CPTPP, ${ }^{2}$ and numerous bilateral and sectoral agreements - the US has substantially withdrawn from participating. Since the US exit from the TPP in 2017, there has been a steady march of new trade agreements across the Asia-Pacific region that do not include the United States. If this trend continues, there is a serious danger that the US will miss its window of opportunity to shape trade rules and norms within the largest and most rapidly growing region in the world.

\section{The RCEP Confirms Rules-Based Trade}

As the United States largely retreated from economic engagement in Asia over the past four years, fifteen countries in the Asia-Pacific region, including China, Japan, Australia and ASEAN members, signed a major new trade agreement, the Regional Comprehensive Economic Partnership (RCEP), which covers thirty percent of global GDP. Beijing has been a promoter of RCEP since day one. Then, as the US backed away from the regional stage and pursued a trade policy based on unilateralism and bilateral negotiations, Chinese leaders used that vacuum to portray Beijing as the reliable partner of choice for economic growth, trade, and investment. But to describe RCEP as a China-led trade initiative misses broader trends in Asia, where countries are focused on diversifying trading partners, solidifying supply chains, and achieving economic and job growth through trade agreements.

The RCEP negotiations were grueling. They went on for eight long years with many ups and downs. Most notably, RCEP members were confronted with a major setback when India withdrew from the negotiations. While India's exit was not a welcome move, in many respects it made the deal easier to conclude because New Delhi was blocking progress on many important issues, including market access, intellectual property protection, and investment.

Overall, the RCEP is less ambitious than the Comprehensive and Progressive Agreement for Trans-Pacific Partnership (CPTPP) with respect to market access (including tariffs) and trade and investment "rules." That said, the effects of RCEP are impressive and likely to be far-reaching despite not being as rigorous as the

\footnotetext{
${ }^{1}$ RCEP is the Regional Comprehensive Economic Partnership and is a free trade agreement that was signed on 15th November 2020. The nations that signed were Australia, Brunei, Cambodia, China, Indonesia, Japan, Laos, Malaysia, Myanmar, New Zealand, the Philippines, Singapore, South Korea, Thailand and Vietnam. The 15 member countries embraced about $30 \%$ of global GDP at the time of signing.

${ }^{2}$ TPP is the acronym for Trans-Pacific Partnership. The history and outcome of TPP is described in the main body of this essay.
} 
CPTPP. It incentivizes supply chains across the region while also putting many political sensitivities to the side.

Being arguably the largest free trade agreement in history connecting $30 \%$ of the world's people and output, and mainly an ASEAN-centered agreement also means that the RCEP is likely to improve and expand over time as other regional agreements have. That said, it falls short on e-commerce, and is silent on labor, the environment and state-owned enterprises - all key chapters in the CPTPP. However, regardless of their differences, both the RCEP and the CPTPP are powerful responses to growing protectionism and put Asian countries on the map as key trade rulemakers. By signing the RCEP agreement, the member countries made a forceful statement in favor of trade liberalization, open markets, and the importance of rules to govern flows of goods and services.

Furthermore, trade agreements, especially those concluded between multiple parties, are not just about tangible market access benefits and the wording of rules provisions. RCEP promotes the further integration of the member economies through common rules and lower tariff rates. It solidifies bonds between trade negotiators and ministers, from Beijing to Jakarta to Wellington, which will carry over to other fora and initiatives. And we can also expect geopolitical impacts as the fifteen countries chose to work together under the RCEP framework regardless of their differences and their disputes with other parties in the region.

Finally, RCEP is another reminder that our Asian trading partners have developed a confidence about working together without the United States. This is a far cry from the early days of the Trump Administration when the remaining TPP members were doubtful of their ability to go forward without Washington.

\section{The Future of the CPTPP}

Many expected the Trans-Pacific Partnership (TPP) to die a quiet death after the United States exited the agreement in the first week of the Trump administration. That didn't happen. Instead, the regional trade deal lives on internationally as the CPTPP, as well as in numerous provisions of the United States-Mexico-Canada Agreement (USMCA) and the US-Japan phase one trade agreement.

The US exit put the brakes on US participation in a 12-country agreement whose members represented nearly 40 percent of global economic output. It included 30 chapters and state-of-the-art rules on such topics as customs administration, services, technical standards, intellectual property protection, e-commerce, investment, labor, and the environment. It also provided members with unprecedented access to each other's markets by eliminating or lowering tariffs and non-tariff barriers across all sectors, including agriculture. The TPP was envisioned as an open platform that would welcome other participants that could meet its high standards.

For the remaining 11 TPP signatories, the exit of the United States at first threw the agreement into disarray. The loss of the world's biggest market diminished the TPP's appeal, collapsing the share of global Gross Domestic Product (GDP) covered 
by the deal from 40 to 13 percent. However, these remaining countries were also divided. Australia announced that it wanted to move forward without the United States but raised the possibility of including other partners such as Indonesia and China. Chile said that it would pursue bilateral trade deals with Beijing instead.

Japan was especially disappointed and stated that, "The TPP would be meaningless without the United States," adding that the US departure, "destroys the basic balance of gains" from the deal. With time, however, Japan reversed course after a bilateral meeting in February 2017, which resulted in a joint statement that gave Japan tacit approval from Washington to go ahead with the TPP without the United States.

In March of that year, Chile hosted the remaining TPP members, as well as South Korea and China, and by May, the 11 original TPP members were determined to move forward among themselves. While Japanese, Australian, and Vietnamese leadership pushed the negotiation toward a conclusion, others, particularly Canada, began to drag their feet. Ultimately, the 11 countries regrouped and were able to work through their remaining differences, including Canada's concerns that the revised deal did not go far enough in addressing progressive issues, particularly labor rights. Following months of negotiation, the most crucial discussions took place on the margins of the November 2017 APEC (Asia-Pacific Economic Cooperation) Economic Leaders' Meeting in Da Nang, Vietnam and were close to reaching an agreement on what would eventually be called the Comprehensive and Progressive Agreement for Trans-Pacific Partnership, or CPTPP.

The CPTPP members surprised skeptics and concluded their revised agreement in March 2018. The amended agreement put aside some of Washington's core concerns and suspended 22 provisions from the original TPP, a small fraction of the lengthy and detailed text, which included provisions that were most important to the United States and those that had drawn concerns from other countries. Procedural adjustments were also made including the schedule for the agreement's entry into force and accession as well. They also exchanged side letters to address specific concerns. Yet the overwhelming majority of the TPP provisions, including the elimination or reduction of tariffs and increased market access, remained untouched, making the CPTPP one of the broadest and most state-of-the-art trade agreements ever signed.

Ratification followed swiftly in Mexico, Japan, Singapore, New Zealand, Canada and Australia, and the CPTPP officially entered into force between those members in December 2018. Vietnam joined a few weeks later. Three of the CPTPP membersBrunei, Chile and Malaysia-have yet to ratify the deal and bring it into force. This is largely due to domestic politics, but the US absence most likely made ratification less urgent. A number of countries have expressed varying degrees of interest in acceding to CPTPP, with the UK taking the first formal step earlier this year. 


\section{Possible Chinese Participation in the CPTPP}

China has also raised its interest in the CPTPP privately and publicly in recent years. But, recent statements from the most senior leaders have garnered international attention. The motivation and timing of these remarks are curious and could be interpreted seriously or with skepticism. Regardless, they cannot and should not be ignored, particularly by the United States.

At the November 2020 meeting of APEC, President Xi Jinping stated: "We must stay as determined as ever to support the multilateral trading system with the World Trade Organization at its core, promote free and open trade and investment, and make economic globalization more open, inclusive, balanced and beneficial to all. Continued efforts are needed to press ahead with regional economic integration for the early realization of a Free Trade Area of the Asia-Pacific (FTAAP). China welcomes the signing of the Regional Comprehensive Economic Partnership (RCEP) and will favorably consider joining the Comprehensive and Progressive Agreement for Trans-Pacific Partnership (CPTPP)."

From Beijing's perspective, CPTPP accession would allow China to further integrate its economy with others in the region while also reducing its reliance on the US market and its vulnerability to US tariffs and other forms of retaliation. Replacing the United States in this signature Asian trade deal would also represent a major public relations coup.

CPTPP countries are unsure of what to make of Beijing's interest. China is a major trading partner of virtually every country in the Asia-Pacific region with two-way trade with China surpassing two-way trade with the United States for most CPTPP members. That said, China would have a long way to go to demonstrate its CPTPP "readiness," particularly with respect to digital trade, labor, and SOEs.

In the early days of original TPP negotiations, which included the US, the word in Beijing was that it was a US strategy to contain China by enlisting its neighbors in a trade deal without the largest Asian economy. This view changed, however, as negotiations proceeded, an evolution captured in a statement by a Foreign Ministry spokesperson who conveyed China's "open-minded attitude toward TPP."

I will always remember my first trip to Beijing in early 2016, soon after ending my almost three-decade career in the Office of the United States Trade Representative. The TPP talks had just concluded and other countries were lining up to express interest in joining. The lengthy text had been translated into Chinese, and in my meetings with officials from the Chinese government, academia and business community, I was peppered with questions on specific provisions and what they might mean for China, should it consider joining.

But once the US left the deal, the TPP looked dead. Remarkably, with Japan's leadership, the other members decided to go forward without US participation rather than squander all the political will and work they had invested, bringing the CPTPP into effect among seven of the 11 members over two years ago. 
Since then, China has quietly approached certain CPTPP members to learn more about the agreement and informally explore their views on possible Chinese accession. While these overtures have not yet led to anything concrete, they demonstrate a continuing interest, which appears to have risen to a new level with Xi's statement.

A number of considerations seem to be motivating China. First, with the US on the sidelines and with the signing of the RCEP, it would provide another avenue for China to integrate its economy with others in the Asia-Pacific region.

Secondly, it could help reduce China's reliance on the US market and its vulnerabilities to further tariffs and other sanctions emanating from Washington. At the same time, acceding to CPTPP could provide external pressure, similar to the role that World Trade Organization accession played two decades ago, for Beijing to proceed with certain needed domestic reforms, particularly in the services sector.

Finally, it could be a great public relations coup for Beijing to try to convince the world that it is serious about trade liberalization and structural reform while the US remains hesitant in entering into new trade agreements.

Of the eight CPTPP members that have ratified the agreement, Singapore has been most vocal in support of Chinese accession. In an interview with the Nikkei Asian Review a year ago, Prime Minister Lee Hsien Loong said, "Singapore's view is that we welcome China to join."

Japan has been more cautious. A Japanese trade official told Caixin, the Chinese media group, last year, "CPTPP members welcome everybody who is willing to take on the high standard of market access commitments and the high standard rules," but he added that "it is up to China, not CPTPP members, to decide whether China is willing to take on those CPTPP rules."

In a January 2019 meeting, CPTPP members established a detailed accession process that spelled out benchmarks for joining the pact. In particular, they asked candidates to show that they could "comply with all of the existing rules contained in CPTPP." Furthermore, they called for comprehensive market access commitments.

Fulfilling both requirements would be an enormous challenge for China, especially as its economy becomes more state driven. Bringing Chinese practices in line with CPTPP commitments on such matters as state-owned enterprises, labor, e-commerce and IPR would be a heavy lift for China, as would Beijing achieving the high rates of tariff liberalization met by other countries.

This should not mean that working toward accession is a futile exercise, albeit one with a long time horizon. If China were to actually implement the market-opening actions over time to match the positive attitude expressed by $\mathrm{Xi}$, this would be a welcome step. Time will tell whether there is any substance behind Xi's words on CPTPP. 


\section{Agreements with the European Union}

The EU's renewed pursuit of trade deals in the region is notable as well. The EU concluded the Economic Partnership Agreement with Japan in July 2018, establishing the world's largest bilateral trade agreement. The EU also concluded agreements with Singapore in 2018 and put in place its agreement with Vietnam in 2020. Long-running negotiations with ASEAN and certain individual ASEAN members are in various stages, along with more recent negotiations with Australia and New Zealand.

From an economic and geopolitical point of view, the recently announced ChinaEU Investment Agreement (CAI) is most challenging. How might it affect the Biden Administration's work towards building a coordinated trans-Atlantic strategy to counter China's growing assertiveness?

While it won't derail trans-Atlantic cooperation, the CAI which is now not moving forward at the time of writing this essay, it may present some challenges. One of the biggest challenges is that the EU, should it reverse its current position, will need to be in a selling and promotional role as it seeks approval for the CAI from the European Parliament. In doing so, the EU will likely refer to China as an important and trusted partner, running counter to the narrative that the Biden administration will be proposing as it looks to work with Europe and other allies and partners in coordinating a China strategy. Furthermore, the EU may be reluctant to robustly use the measures in its new toolbox against China as European companies expand their investments in China in fear of retribution and counter-retaliation.

As a result, it is important that the US and EU open a dialogue on establishing a joint China strategy early on. In doing so, the Biden team will benefit from listening closely to evolving European views on China, including on the CAI, and work to shape a coordinated strategy that takes these views into account.

\section{The Way Forward}

President Biden has emphasized the importance he attaches to working with allies and partners and through international institutions to achieve policy objectives, rather than to rely on the "go it alone" approach that characterized the Trump presidency. As the Biden team re-engages globally it will find a different Asia than that of four years ago. This is most evident on trade, where RCEP now joins CPTPP as two major regional trade agreements concluded since 2015, and where the large and growing Chinese market has become increasingly important to the countries in the region. US re-engagement in Asia will require recognition and appreciation of, and respect for, these changes before the United States puts new ideas and initiatives on the table. It is essential that the US finds new and effective ways to become fully engaged in the Asian economic landscape. 
Wendy Cutler is Vice President at the Asia Society Policy Institute (ASPI) and the managing director of the Washington, D.C. office. She joined ASPI following a distinguished career of nearly three decades as a diplomat and negotiator in the Office of the US Trade Representative (USTR). During her USTR career, she worked on a range of bilateral, regional, and multilateral trade negotiations and initiatives, including the Trans-Pacific Partnership, US-China negotiations, and the WTO Financial Services negotiations. She has published a series of ASPI papers on the Asian trade landscape and serves as a regular media commentator on trade and investment developments in Asia and the world.

Open Access This chapter is licensed under the terms of the Creative Commons AttributionNonCommercial-NoDerivatives 4.0 International License (http://creativecommons.org/licenses/bync-nd/4.0/), which permits any noncommercial use, sharing, distribution and reproduction in any medium or format, as long as you give appropriate credit to the original author(s) and the source, provide a link to the Creative Commons license and indicate if you modified the licensed material. You do not have permission under this license to share adapted material derived from this chapter or parts of it.

The images or other third party material in this chapter are included in the chapter's Creative Commons license, unless indicated otherwise in a credit line to the material. If material is not included in the chapter's Creative Commons license and your intended use is not permitted by statutory regulation or exceeds the permitted use, you will need to obtain permission directly from the copyright holder.

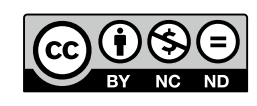

